\title{
Molecular biology of human epidermal receptors, signaling pathways and targeted therapy against cancers: new evidences and old challenges
}

\author{
Paulo Michel Pinheiro Ferreira ${ }^{1 *}$, Cláudia Pessoa ${ }^{2}$ \\ ${ }^{1}$ Department of Biophysics and Physiology, Laboratory of Experimental Cancerology, Federal University of Piaui, Teresina, \\ PI, Brazil. ${ }^{2}$ Department of Physiology and Pharmacology, Federal University of Ceará, Fortaleza, CE, Brazil
}

\begin{abstract}
Human epidermal receptors (HER1/2/3/4) belong to the class of receptor-type tyrosine kinases. After binding a ligand, dimerization, it will ocurr activation of intracellular kinases after two-dimensional and cytoplasmic tail reciprocal transphosphorylation. This transphosphorylation recruits signaling pathways such as Ras/Raf/MEK/Erk1-2, PI3-K/AKT and JAK/STAT, which can affect the cell cycle, cytoskeleton reorganization, apoptosis, metastasis, differentiation, angiogenesis and transcription. HER deregulation is found in epithelial, mesenchymal and nervous neoplasms and is associated with poor prognosis and tumor severity. Since HER are promiscuous proteins when subjected to mutations, resultant modifications confer cellular metabolic superiority and activate complex, interconnected and overlapping networks of cytoplasmic signaling. Moreover, overexpression of HER1/2 is involved in tumor resistance to radiation and anti-hormone therapies. Indeed, HER2 expression is up to 100 -fold higher in $25-30 \%$ of invasive breast cancers. These characteristics support the development of resistance to anti-HER $1 / 2$ chemotherapy such as monoclonal antibodies and tyrosine kinase inhibitors. Then, the challenges in research with HER-positive cancers include planning therapeutic strategies against known resistance mechanisms and identifying novel mechanisms as a way to overcome and control cell growth and malignant progression.
\end{abstract}

Uniterms: Human epidermal receptors/molecular biology. Tyrosine kinase. Cancers/resistance. Chemotherapy. Therapeutic strategies.

\section{INTRODUCTION}

Cancer is a worldwide public health problem characterized as a set of nearly 200 types of complex diseases with proliferative, mutational, metabolic and aberrant features and uncontrolled cell growth. Such transformed animal cells can migrate within a tissue and adjacent organs and even to distant areas of the body (metastasis). These properties are generally caused by chronic accumulation of mutations in oncogenes and tumor suppressor and DNA repair genes (Hanahan, Weinberg, 2011; INCA, 2014; Sullivan, Gui, Vander Heiden, 2016).

The World Health Organization estimates 27 million cancer cases up to 2030, with 17 million deaths and

\footnotetext{
*Correspondence: P. M. P. Ferreira. Departamento de Biofísica e Fisiologia. Universidade Federal do Piauí. Avenida Universitária, lado ímpar, 64049-550, Teresina, Piauí, Brasil. E-mail: pmpf@ufpi.edu.br
}

75 million people living with cancer annually, mainly, in low- and middle-income families. Oceania (Australia and New Zealand) has about 313 cases per 100,000 population, the highest incidence of cases among all continents. South America and Brazil have an incidence of 172 cases per 100,000 inhabitants (WHO, 2012).

Epidemiological studies have confirmed the contribution of specific lifestyle factors for the etiology of cancer, making it a preventable disease in about $50 \%$ (Colditz et al., 1996). Moreover, it is estimated that genes contribute to the genesis in only $5 \%$ of cancers, while $95 \%$ of cancers are related to environmental factors, primarily lifestyle (Anand et al., 2008). Environmental reasons greatly differ between populations and include diet, obesity, lack of physical activity, weight at birth, onset age of puberty, microbial infections, alcohol consumption, tobacco, drugs, occupational exposure (water and air) and reproductive causes. All these potentially carcinogenic factors might take years to transform cells and generate 
clinically detectable tumors (Doll, Peto, 1981; Colditz et al., 1996; Dawson, Provenzano, Caldas, 2009).

Tumors have alterations in cell division and in transmission of membrane, cytoplasmic and nuclear signals. Thus, the neoplastic cell has higher biological and metabolic benefits when compared to non-transformed cells: a) genomic instability and chromosomal aberrations (type and number); b) loss of cell division control; c) escape from apoptosis; d) cell immortality due to the activation of telomerase; e) ability to invade nearby tissues or produce metastases; f) induction and formation of new blood vessels (angiogenesis); g) loss of adhesive properties of the plasma membrane that allow recognition and inhibition of cell movement by cell-cell contact; h) loss of function and the ability of differentiation or specialization; i) autocrine and paracrine signaling; $j$ ) self-activation of receptors; k) escape from immune destruction; 1) promotion of inflammation; and $\mathrm{m}$ ) cellular deregulation of metabolism, since changes in the levels of specific metabolites, such as 2-hydroxyglutarate, fumarate, succinate, aspartate and reactive oxygen species, can result in altered cell signalling, enzyme activity and/or metabolic flux. Of the some acquired hallmark capabilities, seven demonstrably involve contributions by stromal cells of the tumor microenvironment. Stromal cells can be divided into three general classes - infiltrating immune cells, cancerassociated fibroblastic cells and angiogenic vascular cells - and provide multiple functional contributions to tumorigenesis. Notably, the importance of each stromal cell varies with tumor type and organ, controlled by parameters of the distinctive tumor microenvironment and underlying oncogenetic alterations in cancer cells and cancer stem cells that arise in primary tumors, and their invasive and metastatic colonizations (Weinberg, 2008; Hanahan, Weinberg, 2011; Hanahan, Coussens, 2012; Sullivan, Gui, Vander Heiden, 2016).

Most of assimilated capabilities and resistance by tumor cells are associated with alterations in receptors, such as human epidermal receptors (HER), G-proteincoupled receptors (GPCRs), intracellular receptors (AR, androgen receptors; ER, estrogen receptors; GR, glucocorticoid receptors; TR, thyroid hormone receptor) and channel-linked receptors (also called ligand-gated ion channels). HER comprise a class of 4 members - HER1, HER2, HER 3 and HER 4 - also called ErbB (1, 2, 3 and $4)$. They are essential for the maintenance and normal development of many organs and systems and belong to a very evolutionarily diverse family of proteins expressed in epithelial, mesenchymal and nervous tissues (Marmor, Skaria, Yarden, 2004; Burness, Grushko, Olopade, 2010; Kingwell, 2016). HER are widely studied for their ubiquitous role in physiology and cancer (Lassus et al., 2006). Given the importance of HER receptors in tumor progression, this study reviewed the biology of this class of receptors and molecular mechanisms responsible for the pathological activation pathways involved in malignant transformation.

\section{HUMAN EPIDERMAL RECEPTORS: TYROSINE KINASE STRUCTURE, LIGANDS AND ACTI- VATION OF RECEPTORS}

HER are membrane receptors classically belonging to the large family of protein-tyrosine kinases, which comprises 90 members, of which 58 act as membrane receptors (tyrosine kinases receptors - TKRs)(Lemmon, Schlessinger, 2010). These receptors possess: a) an amino-terminal extracellular domain with 643-652 residues subdivided into 4 subdomains rich in leucine and cysteine used for recognition and binding of the ligand; b) a transmembrane domain with 19-25 hydrophobic amino acids that crosses the plasma membrane and c) an intracellular portion of approximately 550 amino acids with a juxtamembrane segment, a kinase subdomain and a carboxy-terminal cytoplasmic tail (Yarden, Sliwkowsk, 2001; Lemmon, Schlessinger, 2010; Morel et al., 2014) (Figure 1). The JM segment has two cytoplasmic and two extracellular isorfoms, the latter being identified in several organs such as adrenal glands, heart, kidneys, cerebellum, cerebral cortex and eyes and in the spinal cord of rodents (Elenius et al., 1997). There is high homology in the kinase domain (59-81\%) between the four types of receptors, with larger differences in the carboxy-terminal tail (only $11-25 \%$ of parallelism) (Jin, Esteva, 2008).

HER genes are found in chromosomes 7 (HER1), 17 (HER2), 12 (HER3) and 2 (HER4), and mutations in any of these genes can cause embryonic or perinatal lethality. HER 1 gene inactivation in mice leads to the digestive tract, skin and lungs, and blocking of HER1dependent signaling pathways in cardiac myocytes causes changes (arrhythmias, for example) during rest and in situations of increased metabolic demand (Miettinen et al., 1995). HER2 and HER4 ligands are capable of inducing differentiation of ventricular tissue and HER3 knockout mice have dilated and thinner atrioventricular valves, which causes embryo deaths before the 15th day of pregnancy (Earp et al., 1995; Riethmacher et al., 1997). Astrogenesis occurs later in development than does neurogenesis, and nuclear HER4 signaling seems to play a central role in creating this delay by inhibiting the onset of astrogenesis (Sardi et al., 2006). 


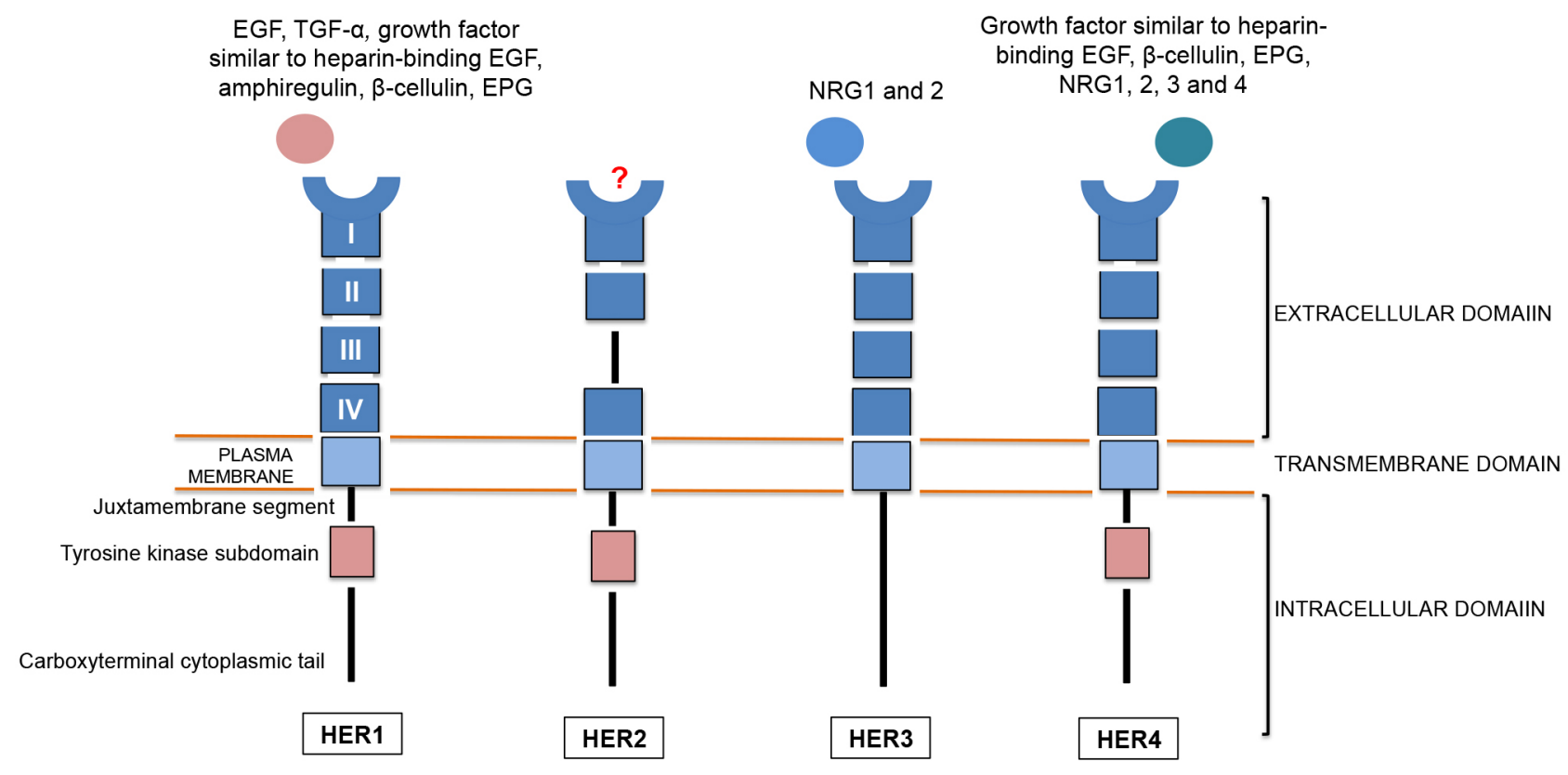

FIGURE 1 - General arrangement of receptors HER1/2/3/4 and their natural soluble ligands. The extracellular domain has four subdomains, and domains I and II are involved in binding the ligand. The carboxy-terminal tail contains tyrosine residues that can be phosphorylated. HER3 does not have a tyrosine kinase domain. To date, there are no known ligands for HER2. Epidermal growth factor (EGF), transforming growth factor alpha (TGF- $\alpha$ ), amphiregulin, $\beta$-cellulin, growth factor similar to heparin-binding EGF, epiregulin (EPG) and neuregulin (NRG).

Each member of the HER family can make combinations and create 28 homo- or heterodimers, resulting in a diversity of receptors. Combined with 11 growth factors, 28 dimers can generate more than 600 receptor-ligand complexes (Blobel, 2005). Although HER2 has no known specific ligand, it serves as an excellent "partner" for transphosphorylations, acting as a co-receptor for other HER members, which may or not have their extracellular ligands bound (Yarden, Sliwkowsk, 2001; Marmor, Skaria, Yarden, 2004). This high degree of flexibility allows distinct responses to external stimuli in different microenvironmental contexts and the integration of stimuli activate cellular functions.

HER 1 is often stimulated by dimerization with other TKRs and also with heterologous receptors, such as GPCRs (Burness, Grushko, Olopade, 2010).

HER2 is the most common partner of the HER family due to intrinsic interactions that makes it constitutively available for dimerizations and the HER2 heterodimer combinations with HER1 or HER3 exhibit robust signaling activity. HER2 can stabilize the conformation of HER 1 receptors, and it enhances dimerization and phosphorylation in the absence of ligands and alters the endocytosis process and traffic of intracellular vesicles (Prenzel et al., 2000). Furthermore, the production of HER2 heterodimers increases the affinity of other members of the family for their respective ligands (Citri, Yarden, 2006).

HER3 does not have intrinsic tyrosine kinase activity, and it generates inactive HER3/HER3 dimers, but it can form heterodimers and be phosphorylated by HER2 or HER 4 when activated by HER3 ligands (neuregulin 1 and 2) (Yarden, Sliwkowsk, 2001; Vlahovic, Crawford, 2003; Marmor, Skaria, Yarden, 2004). Although it is accepted that HER3 lacks functional residues (including aspartate catalytic action), studies have suggested that it conserves its capacity to phosphorylate its own intracellular domain (Shi et al., 2010). After dimerization with HER2, HER3 has dramatically increased affinity for neuregulin and converts its inactive kinase $\mathrm{C}$-terminal portion into an extremely active enzyme to transduce mitogenic signals and to offer many additional phosphorylation sites. HER3 is also a strategic partner, since it does not undergo intralysosomal degradation, being continuously rephosphorylated and recycled by HER 2 overexpression and actively contributing to cell transformation (Citri, Yarden, 2006). Moreover, heterodimers such as HER2/ HER3 and HER3/HER3 are apparently non-functional. However, HER2 is the favorite partner for dimerization with other HER family members and heterodimers with HER 1 and HER 3 promote intense signaling activation. Moreover, despite the absence of tyrosine kinase HER3 
activity and failure to specifically activate cascades of cell cycle, apoptosis regulation, reorganization of the cytoskeleton and differentiation as seen with other members, HER3 might be functionally capable of autophosphorylation (Tzahar et al., 1996; Shi et al., 2010; Ghosh et al., 2011).

HER 1 and HER 4 are the only functionally complete receptors, they show larger numbers of interactions and probably display similar functions at different periods in response to their favored ligands (EGF and NRG, respectively) (Eccles, 2011).

Two-dimensional reciprocal transphosphorylations take place at the cytoplasmic kinase C-terminal domain after dimerization. Thus, although no natural soluble ligands are known for HER2, this receptor also creates heterodimers, as detailed above. Genetically designed mice have shown that in bone marrow cells with mutations in HER genes, there are failures in EGFinduced dimerization, autophosphorylation and activation of signaling pathways. These structural and functional analyses indicate that complementary portions of the two molecules called dimerization arms allow the formation of HER1 complexes because of the establishment of homoand heterodimers (Garrett et al., 2002).

Following two-dimensional reciprocal transphosphorylations, there is no obstruction in the catalytic cleft due to the phosphorylation of the activation loop (providing access to substrate molecules), phosphorylation of tyrosine residues in the C-terminal portion outside the kinase domain, which serve as binding sites for proteins containing the cytoplasmic SH2 (Src homology) domain, and migration of proteins to the inner plasma membrane. These specific proteins interact with plasma membrane phospholipids and proteins and allow activation of downstream signaling pathways and cellular responses (Weinberg, 2008; Wagner et al., 2013).

The juxtamembrane segment of HER 1 also participates in the activation of protein kinases. Specific mutagenesis in C-terminal residues (664-682) of the juxtamembrane region prevents HER 1 activation, especially at positions $664,665,667,668,670,680$, 681 and 682 (Red Brewer et al., 2009). Leukemias and gastrinomas arise in dogs following mutations, deletions and/or substitutions of amino acids in the juxtamembrane domain due to activation of KIT receptor (TRKr) in the absence of ligands, suggesting that this domain has an inhibitory effect on KIT receptors. On the other hand, the Kit proto-oncogene is important for hematopoiesis, survival of melanocytes and development of Cajal cells in the gastrointestinal tract(Weinberg, 2008).

The first HER ligand identified was EGF, a polypeptide of $170 \mathrm{kDa}$, which binds to HER1. Therefore, it was classified as EGFR (epidermal growth factor receptor) and commonly overexpressed in carcinomas (Cohen, 1983). Over the years, many other ligands have been identified, including transforming growth factor alpha (TGF- $\alpha$ ), amphiregulin, $\beta$-cellulin, growth factor similar to heparin-binding EGF, and epiregulin (EPG) that bind to HER1/HER1 homodimers. Neuregulins 1 and 2 (NRG) (synonym: heregulins) bind to HER3/HER3, and $\beta$-cellulin, growth factor similar to heparin-binding EGF, epiregulin and neuregulins (1, 2, 3 and 4) bind to HER4/ HER4. Natural ligands for homodimers HER2/HER2 have not yet been identified (Marmor, Skaria, Yarden, 2004; Blobel, 2005; Eccles, 2011) (Figure 1).

HER ligands arise from transmembrane precursors anchored to the plasma membrane, whose extracellular portion is proteolytically cleaved by enzymes belonging to a family of zinc-dependent metalloproteinases called ADAM, particularly ADAM-10 and ADAM-17, resulting in the release of soluble factors that have been implicated in HER transactivations (Von Minckwitz, 2007; Higashiyama et al., 2008; Tural et al., 2014). HER factors generally bind to cells at short distances from the site of release and may act in autocrine (binding to receptors of the cell itself) or paracrine (binding to neighboring cells) ways (Blobel, 2005).

\section{Signaling pathways}

Human epidermal receptors recruit intracellular second messengers that activate enzymatic and metabolic pathways such as Ras/Raf/MEK/Erk1-2, phosphatidylinositol 3-kinase (PI3-K/AKT), JAK/STAT, phosphatase proteins such as protein tyrosine phosphatase (PTP), phospholipase C gamma (PLC- $\gamma$ ), and protein kinase $\mathrm{C}$ (PKC), among others. These pathways affect the growth and the cell cycle, reorganization of cytoskeleton and apoptosis (and its inhibition), migration, invasiveness, differentiation, angiogenesis, transcription, and other processes that lead to the formation and progression of malignant tumors (Yarden, Sliwkowsk, 2001; Citri, Yarden, 2006; Red Brewer et al., 2009; Wagner et al., 2013; Park, 2014).

The presence of adapter proteins support theories to explain how growth factor receptors activate Ras and acquire specificity in biological responses. Ras (21 kDa) is an intermediate protein belonging to the transduction machinery of mitogenic signals triggered by growth factors known to bind and hydrolyze guanine nucleotides (Figure 2). These adapter proteins such as Grb2, Shc and $\mathrm{Crk}$, have structural domains capable of binding the 
phosphotyrosine C-terminal of ligand-activated receptors (via the $\mathrm{SH} 2$ domain). They have affinity for two sequences rich in proline within the Sos protein (via the SH3 domain), a second adapter protein that replaces Ras-GDP (guanosine diphosphate) (inactive state) by Ras-GTP, activating Ras (Weinberg, 2008). Thus, the activation of the mitogen activated protein kinase (MAPK) pathway - receptor $>$ Grb2 > Sos > Ras/Raf/MEK/Erk1-2 - evokes most phenotypes induced by the transforming Ras oncoprotein, including growth genes, anchorage independence, loss of contact inhibition and morphological changes associated with malignant transformation. At the end of the cascade, Erk $1 / 2$ activate transcription factors to stimulate growth regulators responsible for expression of cyclin D1, Fos, Jun, p2 $1^{\text {Cip } 1}$ and phosphorylation and reconfiguration of proteins associated with chromatin (HGM-14 and histone H3) (Weinberg, 2008; Park, 2014).

Some lines of evidence show that different ligands may promote specific patterns of HER1 phosphorylation, which could dictate different patterns of signaling and cellular responses. For example, TGF- $\alpha$ and amphiregulin are more effective than EGF in inducing invasion and motility. Probably, there is a sustained activation of PLC- $\gamma$ and the MAPK pathway by TGF- $\alpha$ and amphiregulin, while EGF promotes ubiquitination and faster degradation of EGFRs by proteolytic proteasome complexes (Eccles, 2011). Amplifications of Ras/Raf are present in cancer cells continuously stimulated by growth factors such as HER-soluble ligands, autocrine signaling or constitutively activated mutant receptors. $R A S$ gene mutations have been found in colon $(45 \%)$, pancreatic $(90 \%)$, ovarian $(30 \%)$ and papillary thyroid (60\%) carcinomas, and in $15 \%$ of melanomas and $35 \%$ of non-small-cell lung cancers (NSCLC) (Eccles, 2011; Wagner et al., 2013).

PI3-Ks are members of a well-conserved family of intracellular kinases, which phosphorylate the 3'-hydroxyl group of phosphoinositides. Signals that bind to the TKRs and activate PI3-K include platelet-derived growth factor (PGDF), neuronal growth factor (NGF), insulinlike growth factor 1 (IGF-1), interleukin-3 (IL-3) and

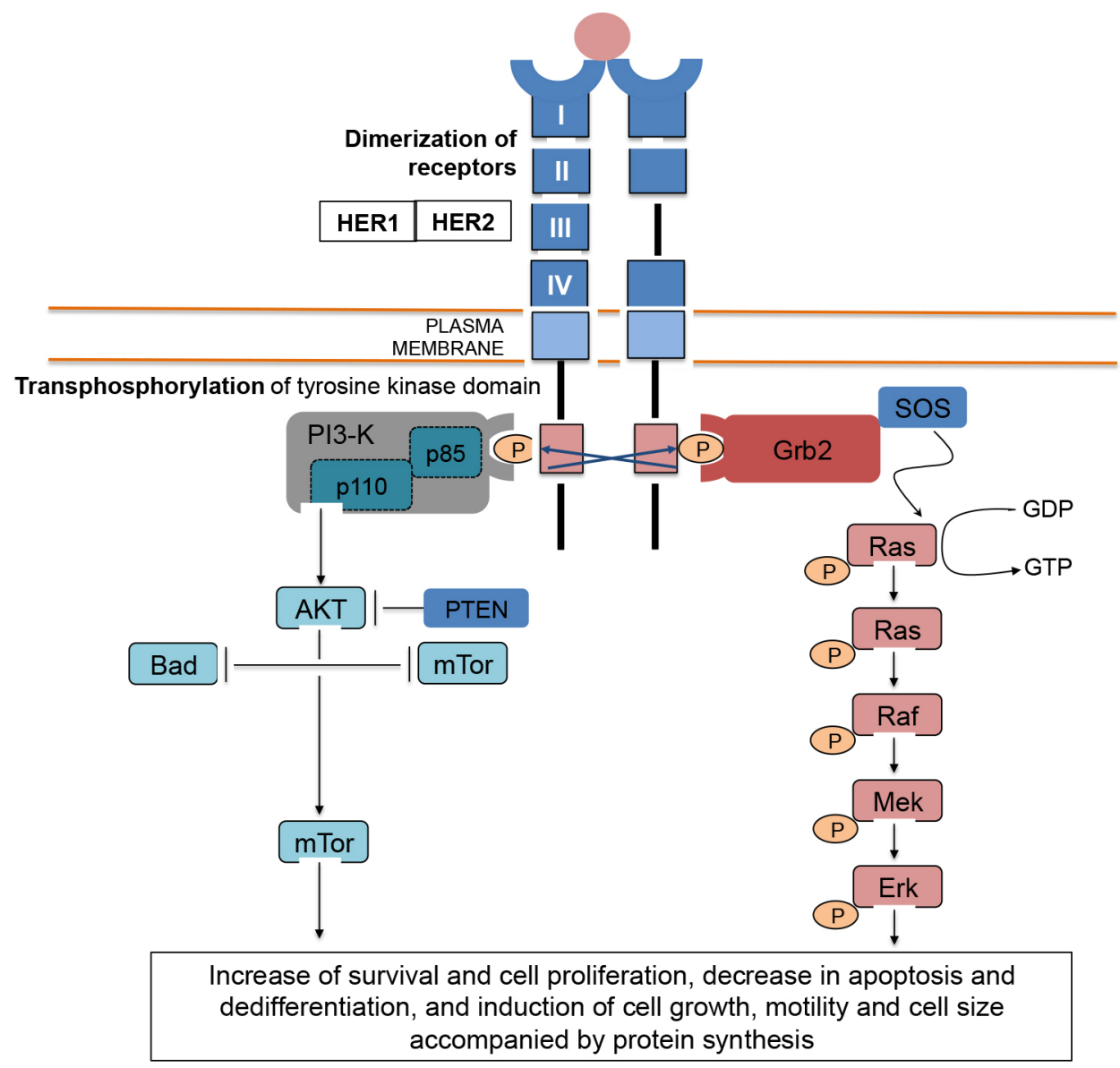

FIGURE 2 - Activation of the cytoplasmic signaling pathways Ras/Raf/MEK/Erk1-2 and phosphatidylinositol 3-kinase (PI3-K/ AKT) following dimerization of human epidermal receptors (e.g., HER1/HER2 heterodimer) resulting from recognition of the receptor extracellular domain by ligands. 
extracellular matrix by binding to integrins (Vivanco, Sawyers, 2002).

Eight types of PI3-Ks found in mammals are classified into Class I (PI3-K $\alpha$, PI3-K $\beta$, PI3-K $\gamma$ and

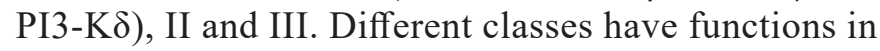
cell signaling and activate distinct signaling pathways to regulate metabolism, survival, cell growth and differentiation and traffic of intracellular vesicles. Members of the PI3-K $\alpha$ class, the most important from the point of view of clinical oncology, are activated by TKRs and heterodimers made up of a regulatory subunit (p85) and a 110-kDa catalytic subunit (p110 , $\mathrm{p} 110 \beta, \mathrm{p} 110 \gamma$ and $\mathrm{p} 110 \delta$ ), being the regulatory subunit an essential component for this interaction. Meanwhile, I $\beta$ components are activated by GPCRs, which are deprived from this subunit. The p $110 \alpha$ catalytic subunit has a dominant role in tumorigenesis, angiogenesis and activation of stromal fibroblastos and is able to phosphorylate phosphatidylinositol 4,5-bisphosphate $\left(\mathrm{PIP}_{2}\right)$ to produce phosphatidylinositol 3,4,5-trisphosphate ( $\mathrm{PIP}_{3}$ ), a pharmacological activity not described for other PI3-K classes that differ in their ability to phosphorylate membrane lipids (Orcy et al., 2008; Fruman, Rommel, 2014).

Lipids, such as PIP $_{3}$, act as docking sites for intracellular proteins and serve to transmit information from the plasma membrane to the cytosol. Many of these molecules bind to cytosolic $\mathrm{PIP}_{3}$ by pleckstrin homology $(\mathrm{PH})$ domains, especially protein kinase $\mathrm{B}(\mathrm{PKB}$, also known as AKT), a serine-threonine kinase that moves to the plasma membrane following PI3-K triggering. Next, the kinase domain of AKT/PKB is phosphorylated at positions 473 (serine) and 308 (threonine) by phosphoinositidedependent kinase-1 (PDK-1), also recruited from the cytoplasm. Biological effects of AKT/PKB are reflected in: i) increased survival (reduced apoptosis) due to Bad protein inactivation; ii) induction of cell proliferation by inhibition of glycogen synthase kinase $3 \beta$ (GSK-3 $\beta$ ); and iii) intensification of cell growth, size and motility, accompanied by increased protein synthesis rate mediated by mTOR protein, a serine-threonine kinase involved in protein synthesis control (Weinberg, 2008; Vivanco, Sawyers, 2002; Fruman, Rommel, 2014). Studies show that about $1 / 3$ of colon carcinomas have mutations within p110 subunits and $30-40 \%$ of the tumors do not exhibit PTEN phosphatase activity due to mutations or DNA methylation that suppresses the PTEN gene. Therefore, there is usually the coexistence of mutations in PI3KA genes (encoding p110 $\alpha$ ), PTEN loss and transforming changes in TKRs (Ludovini et al., 2011; Suda et al., 2012). Investigations have also shown that HER3 displays the
PI3-K/AKT/PKB cascade as the most activated signaling pathways after binding of neuregulins ( 1 and/or 2) and has six binding sites for the regulatory p85 subunit (Eccles, 2011).

JAKs (Janus kinases) are a family of four kinases (JAK1, JAK2, JAK3 and TYK2) of 110-140 kDa associated with different hematopoietic receptors. They mediate signaling processes by transphosphorylation of tyrosine residues of the $\mathrm{C}$-terminal cytoplasmic tail of the receptor and phosphorylation of transcription factors collectively called STAT (signal transducer and activator of transcription) (Figure 3). In mammals, STAT proteins are represented by a family of seven members (STAT1, STAT2, STAT3, STAT4, STAT5A, STAT5B and STAT6) that bind to freshly phosphorylated tyrosine residues through SH2 domains. Following phosphorylation, they undergo dimerization (STAT-STAT) and translocation to the nucleus, where they recognize specific DNA regions to activate or repress transcription. Some proteins whose transcription is activated by STAT-STAT dimers include oncoprotein Myc, cyclins (D1, D2, D3) and antiapoptotic proteins such as BCL- $\mathrm{X}_{\mathrm{L}}$, all involved in survival and cell proliferation (Vahedi et al., 2012; O'Shea, Holland, Staudt, 2013). STAT5, for example, is a partner for HER1 and HER4, and their interaction is required for lactation and embryonic alveolar differentiation (Schulze, Deng, Mann, 2005).

Inactivations of $J A K 1$ and $J A K 2$ genes in mice result in a lethal phenotype due to neurological disorders and absence of erythropoiesis, respectively (Neubauer et al., 1998; Rodig et al., 1998), which probably explains the nonexistence of completely inactivated JAK isoforms in humans. Interleukins, interferons, erythropoietin and thrombopoietin are the most common ligands of JAK/ STAT receptors, explaining why changes in this pathway are associated with hematologic cancers. Hyperactivity of JAK1, JAK2, and JAK3 has been identified in patients with T-cell acute promyelocytic leukemia, B-cell acute myelocytic leukemia, acute myelogenous leukemia and lymphomas (O'Shea, Holland, Staudt, 2013). Amplification of the encoding JAK2 chromosome 9p24 has been reported in 30 to $50 \%$ of Hodgkin lymphoma and mediastinal B-cell lymphoma cases (Joos et al., 2000). In solid tumors, continuous phosphorylation of STAT1, STAT3, and STAT5 has been described in breast, lung, and head and neck cancers, suggesting facilitation by increased autocrine and paracrine release of cytokines and overexpression of JAK/STAT receptor (Sansone, Bromberg, 2012). In most breast and head and neck cancers, STAT3 is constitutively activated and its neutralization causes apoptosis in mammary tumors and melanomas (Weinberg, 2008). 


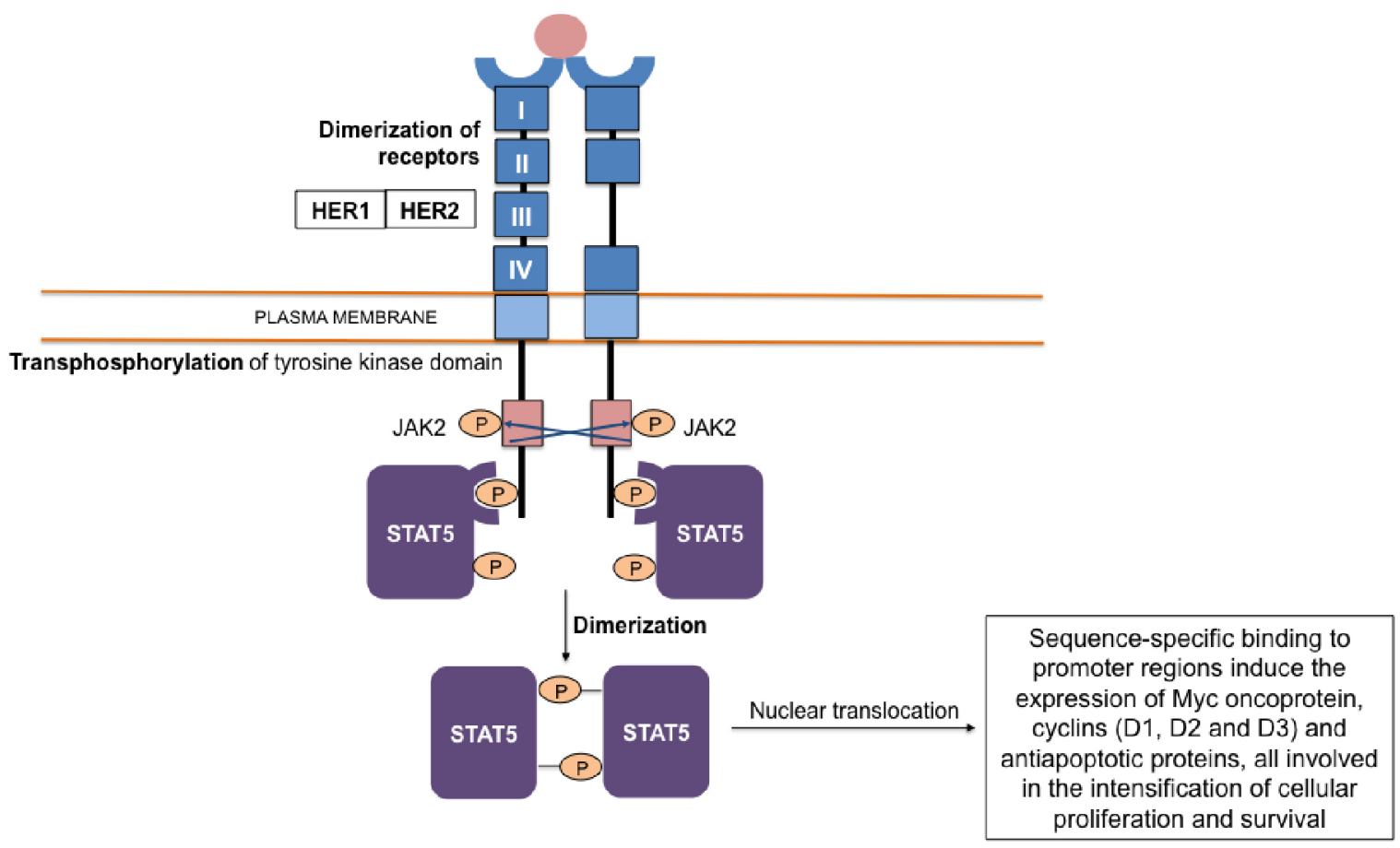

FIGURE 3 - Signaling activation of JAK/STAT pathway by human epidermal receptors (HER). STAT-STAT dimerization may occur between identical or different dimers (e.g., STAT1/STAT2 or STAT5/STAT5).

\section{MALIGNANCY AND DEVELOPMENT OF RESISTANCE}

Investigations have suggested a new mechanism of action for HER in which receptors are translocated to the nucleus and participate in the signaling process. Analysis revealed that the nuclear binding protein EGF has similar molecular weight to the plasma membrane HER1. Monoclonal antibodies produced against the plasma membrane HER1 also recognize nuclear HER1, and the latter has comparable affinity to plasma membrane EGF, though the nucleus has about $10 \%$ fewer receptors (Carpenter, Liao, 2009). Brand et al. (2013) reported that HER3 is expressed in the nucleus of breast (SKBR-3, MCF-7, BT-474, HCC-1954 and BT-549), lung (H226), head and neck (SCC-6 and CCS-1) and colon (LoVo and Caco-2) cell lines. The disruption of HER receptors occurs by a variety of mechanisms, especially receptor overexpression (Mendelsohn, Baselga, 2003; Herbst, Heymach, Lippman, 2008; Lee et al., 2014), overproduction of agonists, receptor overexpression associated with overproduction of ligands, which results in autocrine activation (Mcintyre et al., 2010), mutations that cause constitutive activation of the tyrosine kinase domain (Jaiswal et al., 2013) and endocytosis defects during receptor internalization (Abella, Park, 2009).
HER1 overexpression is found in virtually all epithelial malignancies (lung, colon, prostate, breast, kidney, bladder, melanoma, glioblastoma and head and neck). However, only HER1 overexpression does not transform normal cells into cancer cells, since the HER1/ HER 1 dimer is able to phosphorylate just when it binds one of its extracellular ligands. Tumors or adjacent nonmalignant cells, causing an autocrine or paracrine induction of cell division, can produce EGF or other members of the family of growth factors. In breast cancers, mutations of HERI genes are rare but gene amplification is common (e.g., metaplastic subtypes) (Burness, Grushko, Olopade, 2010). On the other hand, breast cancer basal cells, a subset of triple negative cancers, exhibit elevated HER1 expression, high degree of malignancy, distinct patterns of metastasis (basically to the viscera, liver and brain) and poor prognosis (Dawson, Provenzano, Caldas, 2009). Around 10\% of the Caucasian population and $30-40 \%$ of Asian patients with lung cancers were shown to have mutations in the HERI kinase domain, and its amplification was found in $15 \%$ of patients with adenocarcinomas and in 30\% with squamous cell carcinomas (Herbst, Heymach, Lippman, 2008). Investigations of structural changes revealed that about $40 \%$ of glioblastomas have amplification and overexpression of the HER 1 gene and that approximately half of the patients had a deletion of a specific DNA sequence between exons 2-7, which results in the absence of HER1 domains I and 
II and inability to recognize and bind ligands (Wong et al., 1992). This deletion leads to HER1 oncogenic activation in a similar manner as receptor stimulation in the absence of the extracellular domain.

Changes in HER2 receptors have been detected in $15-20 \%$ of human cancers, including $20 \%$ of ovarian tumors and $10-15 \%$ of gastric tumors. In breast cancer, overexpression of HER2 correlates with poor prognosis, resistance to hormonal treatment and severity of malignancy, and shows correlations with mutations in p53 protein (Mendelsohn, Baselga, 2003; Lassus et al., 2006; Seoane et al., 2010). Many ligands, including NRG variants, are overexpressed, suggesting the possibility of autocrine signaling (Mcintyre et al., 2010). In diffuse types of gastric tumors, immunohistochemistry and fluorescence in situ hybridization (FISH) analysis demonstrated that $21-32 \%$ of European and Asian patients exhibited HER2 overexpression (Bang et al., 2010).

HER3 shows high expression in breast, prostate, bladder, colon, stomach and ovarian cancers, head and neck squamous cell cancer, and melanomas. Detailed studies revealed that the oncogenic activity in HER3 from mutations occurred in $11 \%$ of colon and breast carcinomas and depended on HER 2 and HER 3 changes and ligandindependent activation of the kinase domain (Citri, Yarden, 2006; Lee-Hoeflich et al., 2008; Jaiswal et al., 2013), indicating that HER 3 is a key partner of HER 2 and that its expression is a limiting factor for survival and proliferation induced by HER 2 in breast cancer cells. Moreover, HER3 seems to be the most common partner for dimerizing with HER1 in melanomas and pancreatic cancers (Reschke et al., 2008; Liles et al., 2010).

HER3 and HER4 are likely responsible for resistance to anti-hormone therapies (Sutherland, 2011) and to treatment with paclitaxel due to overexpression of the protein survinin via the PI3-K/AKT/mTOR pathway. Inhibition of HER4 expression may prevent the proliferation of estrogen receptor-positive breast carcinoma cell lines, suggesting a growth promoting effect that is estrogen receptor dependent (Eccles, 2011). Besides, HER 4 gene mutation can be present in breast cancer, prostate cancer, and childhood medulloblastoma, and its downregulation has been demonstrated for all the alternatively spliced isoforms of this receptor in gastric cancer (Nielsen et al., 2014).

HER have also been implicated in all aspects of angiogenesis, invasion and metastasis: alterations in cellcell adhesion and cell matrix, deregulation of proteases and receptors (CXCR4, CD44, and integrins), vascular extravasation and organ-specific colonization (De Luca et al., 2011). HER1 and HER2 overexpression correlates with increased levels of vascular endothelial growth factor (VEGF)-A, -B and -C and microvasculature density. Thus, VEGF, the main angiogenic factor, is induced not only by hypoxia but by HER oncogenes as well, certainly by the PI3-K/AKT pathway. Some cancers have shown a direct association of malignity and invasiveness with cytokine receptors (CXCR-4), ligands (CXCL-12/SDF-1 $\alpha$ ) and HER2 expression (Eccles, 2011). HRG-HER3 complex is able to stimulate metastasis by PI3-K/AKT, since mutations in the regulatory domain of the $\mathrm{p} 85$ subunit inhibit the vascular and tissue motility and invasiveness of breast carcinoma cells (Smirnova et al., 2011).

Dissemination to lymph nodes, blood and bone marrow is indicative of a bad prognosis in the staging of breast cancers. These metastatic cells often overexpress HER1 and HER2 even when this expression does not exist in the primary tumors (Eccles, Paon, 2005). These findings suggest that the spread of cancer cells is a very early event and that HER proteins may contribute to the motility and escape of tumor cells from their primary site.

All genotypic and phenotypic changes in human epidermal receptors and in related cytoplasmic signaling pathways are primarily responsible for the development of resistance to different treatment protocols (Figure 4). HER1 triggering stimulates the AKT/PKB and Ras/ $\mathrm{Raf} / \mathrm{MEK} /$ Erk pathways, and this activation is present in multidrug resistance due to upregulation of MRP-like proteins (multidrug resistance protein) such as MRP1, 3, 5 and 7. Amphiregulin expression has been associated with resistance of MCF-7 cells and breast tumors to cisplatin in patients due to the activation of the EGFR-AKT-MEK cascade. Furthermore, overexpression of HER1 and HER2 is involved in tumor resistance to radiotherapy, since both receptors are overexpressed after exposure to ionizing radiation (Eccles, 2011).

\section{TREATMENT: FROM SURGERY TO THE RE- CEPTOR}

In general, cancer therapy consists of the combination of surgical resection of the tumor with chemotherapy and/ or radiotherapy. In the 1970s, these classic approaches significantly changed with the introduction of the concept of adjuvant treatment. Intensive use of post-surgical protocols, including the combination of different chemotherapies (with different mechanisms of action) with radiotherapy and, more recently, the combination with monoclonal antibodies, has improved treatment outcomes of some types of cancers (Weinberg, 2008; Ferreira et al., 2013).

Progress in cancer biology has revealed that different subtypes of the disease have a distinct prognosis 

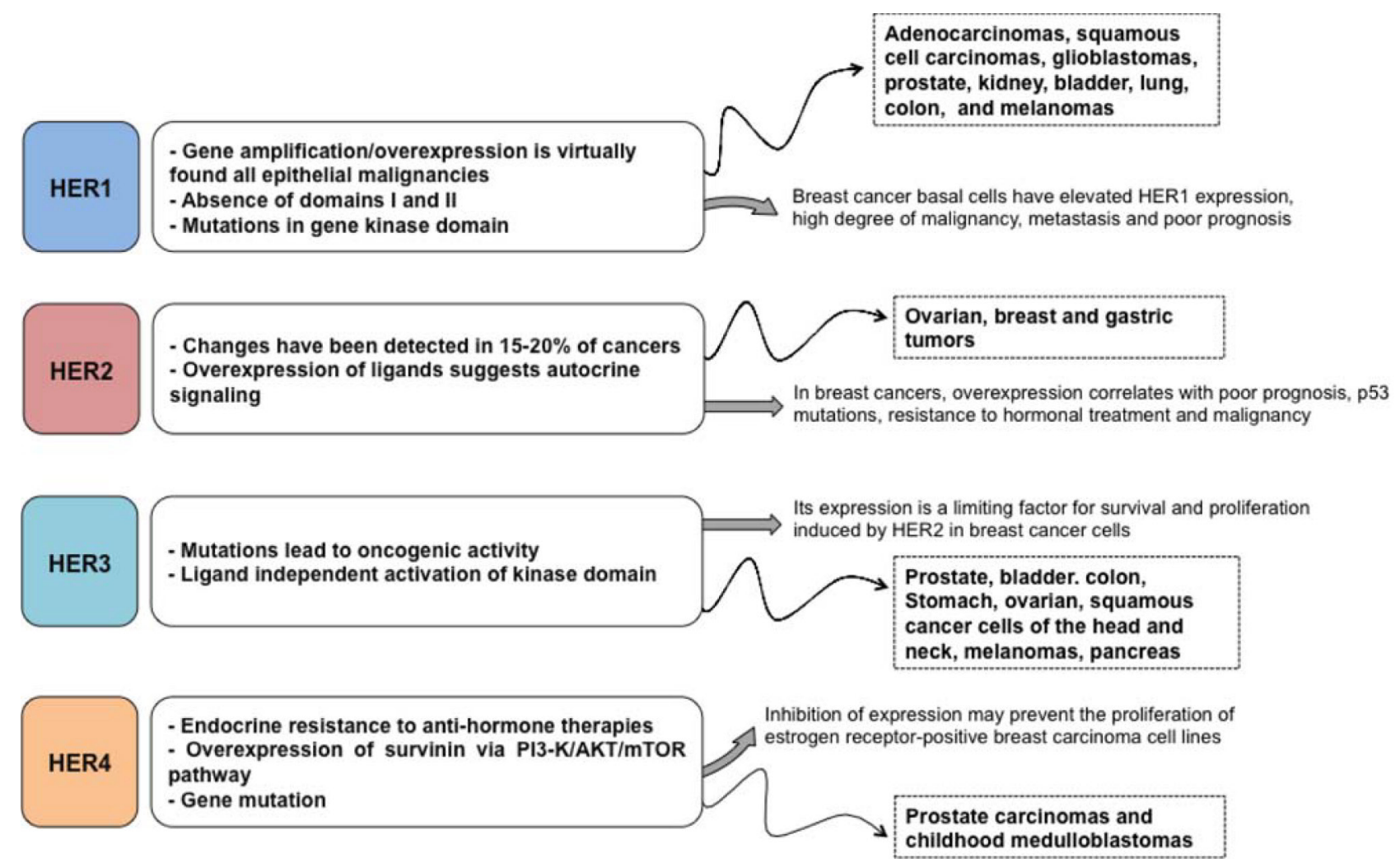

FIGURE 4 - Most common alterations in human epidermal receptors to induce malignancy and development of resistance.

and clinical features, which implies in changeable response profiles for each tumor subtype (Fernandes, Calabrich, Katz, 2009). These findings have been constantly evidenced by the fact that tumors with similar morphologies may have different molecular profiles that are undetectable by pathological examination (Dutra et al., 2009). Taking breast cancer into account, this section describes clinical treatment protocols currently used to treat malignant breast tumors (positive or negative for human epidermal receptors).

Surgery is the main modality of treatment for in situ breast cancers followed by chemotherapy, radiotherapy and adjuvant hormonal therapy (tamoxifen or aromatase inhibitor), but over $90 \%$ of patients with breast cancer undergo surgery. Receptors for estrogen and/or progesterone are present in about $79 \%$ of breast cancers (Wittliff, 1984). Around 30\% of patients are treated with surgery and radiation, $15 \%$ with surgery and multidrug therapy and $21 \%$ with surgery, radiation and multidrug therapy. Chemotherapy may be used before surgery (neoadjuvant therapy), after it (adjuvant) or in replacement of palliative surgery in conditions where surgery is considered an unsuitable option (Weinberg, 2008; Siegel, Naishadham, Jemal, 2013).

Various cytotoxic agents are used in the treatment of advanced breast cancer, especially for triple-negative cases and negative for estrogen and progesterone receptors, including doxorubicin, cyclophosphamide, docetaxel and paclitaxel. One of the most used and recommended protocols by the National Comprehensive Cancer Network (NCCN) includes the combination of doxorubicin and cyclophosphamide followed by paclitaxel. Others that are very often used in chemotherapy are gemcitabine, capecitabine, vinorelbine and pemetrexed (Von Minckwitz, 2007). Many patients who are hormonereceptor positive have shown good clinical responses with tamoxifen. It binds to the estrogen receptor, but does not activate it. Anastrozole and letrozole are aromatase inhibitors that block the formation of the aromatic A ring of estradiol and can be used as alternative antiestrogenic compounds that have fewer side effects than tamoxifen (Xu et al., 2015; Ohno, 2016).

Among the pharmacological innovations, the development of targeted therapies has substantially increased life expectancy, especially for HER2-positive patients and those with tumors that are highly aggressive and of undefined prognosis. Indeed, the search for alterations in breast cancers revealed that HER2 is up to 100 -fold higher in $25-30 \%$ of invasive breast cancers, whereas $10-20 \%$ are triple-negative, negative 
for estrogen and progesterone receptors and without overexpression of HER2 (Lee et al., 2014). All HER members are overexpressed in a wide variety of breast cancers, basically, in the following order: HER2 $>$ HER1> HER3> HER4 (Mcintyre et al., 2010). Breast cancers can express from 25 to 50 copies of HER genes and up to 2 million receptors per cell. This property makes the tumor (and its cells) a relatively selective therapeutic target, since normal tissue shows the absence or low expression of receptors. The heart is an exception, which explains the cardiotoxicity and cardiomyopathy related to the target-directed chemotherapy against HER proteins, indicating higher expression of these receptors in cardiac myocytes, especially when administered in combination with anthracyclines, which has discouraged this type of clinical procedure (Procter et al., 2010).

HER2-positive cancers exhibit unique biological characteristics, including increased sensitivity to doxorubicin (probably because of HER2 co-expression with topoisomerase II, a target enzyme for this anthracycline) and relative refractoriness to antisteroid agents, partially showing an inverse relationship between HER2 expression level and estrogen receptors (Gatza et al., 2011).

Two classes of drugs against HER receptors have reached clinical phases: monoclonal antibodies against the extracellular portion of the receptor and tyrosine kinase inhibitors (TKIs). Trastuzumab is a humanized monoclonal antibody (Figure 5) directed to the domain IV of HER2 extracellular juxtamembrane segment (Eccles, 2011). In addition to the direct action on HER2, trastuzumab promotes its internalization and degradation by the ubiquitin-proteasome pathway and causes antibody-depedent cell-mediated cytotoxicity by natural killer (NK) leukocytes (Shuptrine, Surana, Weiner, 2012). This drug was approved as part of the protocol to treat women with breast cancers that markedly overexpress HER2, which consists of a) doxorubicin, cyclophosphamide and paclitaxel or docetaxel; b) carboplatin, or docetaxel or c) anthracycline. In metastatic cancers, trastuzumab is combined with paclitaxel as first choice against tumors that overexpress HER 2 or as single agent in cancers that overexpress HER2 in patients who have already received different treatment protocols. Pertuzumab is another humanized monoclonal antibody that recognizes the HER2 extracellular segment (domain II). It has been prescribed in clinical trials for patients who have not been treated with anti-HER2 and anti-metastatic chemotherapies in association with trastuzumab and docetaxel against metastatic breast carcinomas (Franklin et al., 2004). As both HER2 and
HER4 are expressed in adult cardiomyocytes and since NRG promotes survival of isolated cardiomyocytes, it is possible that ERBB4 has a role in trastuzumab-induced cardiotoxicity (Fuchs et al., 2003). The role of HER4 in cancer biology needs more study, with one important reason being to determine how the blockade of HER4 by multitargeted HER-kinase inhibitors impacts clinical response.

TKIs are small molecules that interact with the kinase domain of HER. Gefitinib (Iressa ${ }^{\circledR}$, AstraZeneca) reversibly inhibits the autophosphorylation of tyrosine kinase in EGFR and obstructs downstream signaling pathways (Figure 4). Meanwhile, lapatinib (Tykerb ${ }^{\circledR}$, GlaxoSmithKline) is a reversible autophosphorylation inhibitor of tyrosine kinase in both HER1 and HER2 with oral effectiveness and was approved for clinical trials by the Food and Drug Administration (FDA) (Ryan et al., 2008). Lapatinib also inhibits a form called p95HER2 or truncated HER2, whose extracellular domain that binds to trastuzumab is absent, which confers drug resistance (Scaltriti et al., 2007). After lapatinib showed antitumor activity in xenograft models and in phase I and II trials, its efficacy in combination with capecitabine was evaluated in phase III clinical trials in women with HER2-positive metastatic breast cancers who progressed after treatment with anthracyclines, taxanes and trastuzumab. This study concluded that combined therapy provided improved progression-free survival (8.4 vs 4.4 months, $\mathrm{p}<0.001$, $\mathrm{n}=324)$ and higher response rate when compared to capecitabine monotherapy (Geyer et al., 2006).

The addition of lapatinib to letrozole trials resulted in a significantly lower risk for cancer progression in women with HER $2^{+}$tumors receiving first-line therapy for metastatic breast cancer in comparison with letrozole alone (Schwartzberg et al., 2010). Progression-free survival was also higher in patients who received chemotherapy or endocrine therapy plus lapatinib, but high levels of heterogeneity were found. Regarding adverse events, groups receiving chemotherapy or endocrine therapy plus lapatinib displayed higher rates of neutropenia, diarrhea, and rash (Schwartzberg et al., 2010; Botrel, Paladini, Clark, 2013).

Despite responses to treatment with trastuzumab for HER2-positive tumors, relapses after early responses were observed in 50-66\% of HER2-positive patients (Rexer, Arteaga, 2012). When resistance has occurred, there is no effective drug able to block the progression of the disease. Accordingly, there has been much research invested to try to elucidate the mechanisms responsible for the development of resistance. Many mechanisms of resistance have been described. The most important 


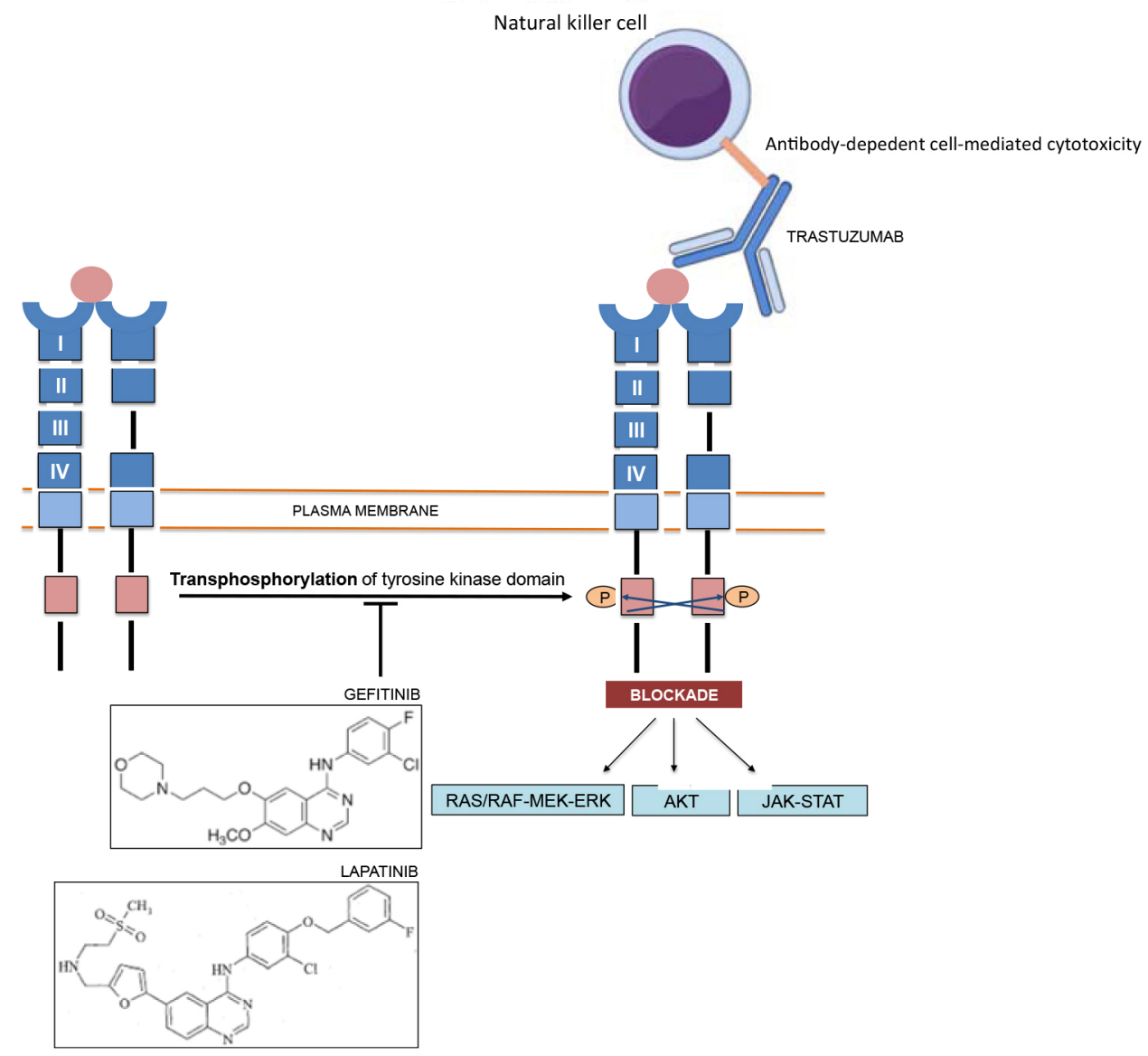

FIGURE 5 - Mechanisms of action of the two classes of drugs against HER receptors that have reached clinical phases: monoclonal antibodies (trastuzumab) and tyrosine kinase inhibitors (TKIs) (gefitinib and lapatinib).

mechanisms include triggering the PI-3K/AKT/ mTOR pathway and alternative routes resulting from the activation of insulin-like growth factor receptor (IGFr), hepatic growth factor receptor (HGFr), loss of HER2 overexpression, reduction of PTEN activity, amplification of cyclin E, interaction of HER2 with other TKRs and presence of truncated receptors (e.g., p95HER2). The incidence of resistance for anti-HER2 treatments is higher than the frequency of molecular alterations, showing that there are other ways to acquire resistance (Spector, Blackwell, 2009; Scaltriti et al., 2011).

\section{CONCLUSION}

HER are promiscuous proteins regarding ligands and production of dimers, and their genes are habitually exposed to mutations that confer metabolic advantages to the cells. Cytoplasmic signaling networks involving receptors and resulting from phosphorylation are extremely multifaceted, intricate and overlapping. These biological characteristics promote the development of resistance even to anti-HER chemotherapies. Therefore, a chief challenge in the study of cancers with positivity for HERtype receptors is, on the one hand, to design therapeutic strategies against known resistance mechanisms and, on the other hand, to identify novel mechanisms of resistance to provide approaches to control cell growth and malignant progression.

\section{ACKNOWLEDGMENTS}

The authors thank the Brazilian agency "Conselho Nacional de Desenvolvimento Científico e Tecnológico" (CNPq) for fellowship awards (Process \#301976/2013-9).

\section{REFERENCES}

ABELLA, J.V.; PARK, M. Breakdown of endocytosis in the oncogenic activation of receptor tyrosine kinases. Am. J. Physiol. Endocrinol. Metab., v.296, n.4, p.973-984, 2009. 
ANAND, P.; KUNNUMAKKARA, A.B.; SUNDARAM, C.; HARIKUMAR, K.B.; THARAKAN, S.T.; LAI O.S.; SUNG, B.; AGGARWAL, B.B. Cancer is a preventable disease that requires major lifestyle changes. Pharm. Res., v.25, n.9, p.2097-2116, 2008.

BANG, Y.J.; VAN CUTSEM, E.; FEYEREISLOVA, A.; CHUNG, H.C.; SHEN, L.; SAWAKI, A.; LORDICK, F.; OHTSU, A.; OMURO, Y.; SATOH, T.; APRILE, G.; KULIKOV, E.; HILL, J.; LEHLE, M.; RÜSCHOFF, J.; KANG, Y.K.; TOGA TRIAL INVESTIGATORS. Trastuzumab in combination with chemotherapy versus chemotherapy alone for treatment of HER2-positive advanced gastric or gastro-oesophageal junction cancer (ToGA): A phase 3, open-label, randomised controlled trial. Lancet, v.376, n.9742, p.687-697, 2010.

BURNESS, M.L.; GRUSHKO, T.A.; OLOPADE, O.I. Epidermal growth factor receptor in triple-negative and basal-like breast cancer: promising clinical target or only a marker? Cancer J., v.16, n.1, p.23-32, 2010.

BLOBEL, C.P. ADAMs: key components in EGFR signalling and development. Nat. Rev. Mol. Cell Biol., v.6, n.1, p.3243, 2005.

BOTREL, T.E.; PALADINI, L.; CLARK, O.A. Lapatinib plus chemotherapy or endocrine therapy (CET) versus CET alone in the treatment of HER-2-overexpressing locally advanced or metastatic breast cancer: systematic review and meta-analysis. Core Evid., 8, 69-78, 2013.

BRAND, T.M.; IIDA, M.; LUTHAR, N.; WLEKLINSKI, M.J.; STARR, M.M.; WHEELER, D.L. Mapping C-terminal transactivation domains of the nuclear HER family receptor tyrosine kinase HER3. PLoS ONE, v.8, n.8, p.e71518, 2013.

CARPENTER, G.; LIAO, H.J. Trafficking of receptor tyrosine kinases to the nucleus. Exp. Cell Res., v.315, n.9, p.1556$1566,2009$.

CITRI, A.; YARDEN, Y. EGF-ERBB signalling: towards the systems level. Nat. Rev. Mol. Cell Biol., v.7, n.7, p.505516, 2006.

COHEN, S. The epidermal growth factor (EGF). Cancer, v.51, n.1, p.1787-1791, 1983.
COLDITZ, G.A.; DEJONG, D.; HUNTER, D.J.; TRICHOPOULOS, D.; WILLETT, W.C. Harvard report on cancer prevention. Causes of human cancer. Cancer Causes Control, v.7, n.1, p.1-59, 1996.

DAWSON, S.J.; PROVENZANO, E.; CALDAS, C. Triple negative breast cancers: clinical and prognostic implications. Eur. J. Cancer, v.45, n.1, p.27-40, 2009.

DE LUCA, A.; GALLO, M.; ALDINUCCI, D.; RIBATTI, D.; LAMURA, L.; D’ALESSIO, A.; DE FILIPPI, R.; PINTO, A.; NORMANNO, N. Role of the EGFR ligand/ receptor system in the secretion of angiogenic factors in mesenchymal stem cells. J. Cell Physiol., v.226, n.8, p.2131-2138, 2011.

DOLL, R.; PETO, R. The Causes of Cancer: Quantitative Estimates of Avoidable Risks of Cancer in the United States Today. J. Natl. Cancer Inst., v.66, n.6, p.1191-1308, 1981.

DUTRA, M.C.; REZENDE, M.A.; ANDRADE, V.P.; SOARES, F.A.; RIBEIRO, M.V.; PAULA, E.C.; GOBBI, H. Imunofenótipo e evolução de câncer de mama: comparação entre mulheres muito jovens e mulheres na pós-menopausa. Rev. Bras. Gincecol. Obstet., v.31, n.2, p.54-60, 2009.

EARP, H.S.; DAWSON, T.L.; LI, X.; YU, H. Heterodimerization and functional interaction between EGF receptor family members: a new signaling paradigm with implication for breast cancer research. Breast Cancer Res. Treat., v.35, n.1, p.115-132., 1995.

ECCLES, S.A.; PAON, L. Breast cancer metastasis: when, where, how? The Lancet, v.365, n.9464, p.1006-1007, 2005.

ECCLES, S.A. The epidermal growth factor receptor/Erb-B/ HER family in normal and malignant breast biology. Int. J. Dev. Biol., v.55, n.9, p.685-696, 2011.

ELENIUS, K.; CORFAS, G.; PAUL, S.; CHOI, C.J.; RIO, C.; PLOWMAN, G.D.; KLAGSBRUN, M. A novel juxtamembrane domain isoform of HER4/ErbB4. Isoformspecific tissue distribution and differential processing in response to phorbol ester. J. Chem. Biol., v.272, n.42, p.26761-26768, 1997.

FERNANDES, G.D.S.; CALABRICH, A.; KATZ, A. Câncer de mama triplo-negativo : aspectos clínicos, laboratoriais e terapêuticos. Gene, v.19, n.2, p.76-82, 2009. 
FERREIRA, P.M.P.; LIMA, D.J.B.; DEBIASI, B.W.; SOARES, B.M.; MACHADO, K.C.; NORONHA, J.C.; RODRIGUES, D.J.; SINHORIN, A.P.; PESSOA, C.; VIEIRA-JÚNIOR, G.M. Antiproliferative activity of Rhinella marina and Rhaebo guttatus venom extracts from Southern Amazon. Toxicon, v.72, n.1, p.43-51, 2013.

FRANKLIN, M.C.; CAREY, K.D.; VAJDOS, F.F.; LEAHY, D.J.; DE VOS, A.M.; SLIWKOWSKI, M.X. Insights into ErbB signaling from the structure of the ErbB2-pertuzumab complex. Cancer Cell, v.5, n.4, p.317-328, 2004.

FRUMAN, D.; ROMMEL, C. PI3K and cancer: lessons, challenges and opportunities. Nat. Rev. Drug Discov., v.13, n.2, p.140-156, 2014.

FUCHS, I. B.; LANDT. S.; BUELER, H.; KUEHL, U.; COUPLAND, S.; KLEINE-TEBBE, A.; LICHTENEGGER, W.; SCHALLER, G. Analysis of HER2 and HER4 in human myocardium to clarify the cardiotoxicity of trastuzumab (Herceptin). Breast Cancer Res. Treat., v.82, n.1, p.23-28, 2003.

GARRET, T.P.; MCKERN, N.M.; LOU, M.; ELLEMAN, T.C.; ADAMS, T.E.; LOVRECZ, G.O.; ZHU, H.J.; WALKER, F.; FRENKEL, M.J.; HOYNE, P.A.; JORISSEN, R.N.; NICE, E.C.; BURGESS, A.W.; WARD, C. W. Crystal structure of a truncated epidermal growth factor receptor extracellular domain bound to transforming growth factor alpha. Cell, v.110, n.6, p.763-773, 2002.

GATZA, M.L.; KUNG, H.N.; BLACKWELL, K.L.; DEWHIRST, M.W.; MARKS, J.R.; CHI, J.T. Analysis of tumor environmental response and oncogenic pathway activation identifies distinct basal and luminal features in HER2-related breast tumor subtypes. Breast Cancer Res., v.13, n.3, p. R62, 2011.

GEYER, C.E.; FORSTER, J.; LINDQUIST, D.; CHAN, S.; ROMIEU, C.G.; PIENKOWSKI, T.; JAGIELLOGRUSZFELD, A.; CROWN, J.; CHAN, A.; KAUFMAN, B.; SKARLOS, D.; CAMPONE, M.; DAVIDSON, N.; BERGER, M.; OLIVA, C.; RUBIN, S.D.; STEIN, S.; CAMERON, D. Lapatinib plus capecitabine for HER2positive advanced breast cancer. N. Eng. J. Med., v.355, n.26, p.2733-2743, 2006.
GHOSH, R.; NARASANNA, A.; WANG, S.E.; LIU, S.; CHAKRABARTY, A.; BALKO, J.M.; GONZÁLEZANGULO, A.M.; MILLS, G.B.; PENUEL, E.; WINSLOW, J.; SPERINDE, J.; DUA, R.; PIDAPARTHI, S.; MUKHERJEE, A.; LEITZEL, K.; KOSTLER, W.J.; LIPTON, A.; BATES, M.; ARTEAGA, C.L. Trastuzumab has preferential activity against breast cancers driven by HER2 homodimers. Cancer Res., v.71, n.5, p.1871-1882, 2011.

JIN, Q.; ESTEVA, F.J. Cross-talk between the ErbB/HER family and the type I insulin-like growth factor receptor signaling pathway in breast cancer. J. Mammary Gland. Biol. Neoplasia, v.13, n.4, p.485-498, 2008.

HANAHAN, D.; WEINBERG, R.A. Hallmarks of cancer: the next generation. Cell, v.144, n.5, p.646-674, 2011.

HANAHAN, D.; COUSSENS, L.M. Accessories to the crime: functions of cells recruited to the tumor microenvironment. Cancer Cell, v.21, n.3, p.309-322, 2012.

HERBST, R.S.; HEYMACH, J.V.; LIPPMAN, S.M. Molecular origins of cancer: Lung cancer. N. Eng. J. Med., v.359, n.13, p.1367-1380, 2008.

HIGASHIYAMA, S.; IWABUKI, H.; MORIMOTO, C.; HIEDA, M.; INOUE, H.; MATSUSHITA, N. Membraneanchored growth factors, the epidermal growth factor family: beyond receptor ligands. Cancer $S c i$., v.99, n.2, p.214-220, 2008.

INSTITUTO NACIONAL DO CÂNCER. INCA. Como é o processo de carcinogênese? Avaliable at: <http://www. inca.gov.br/conteudo_view.asp?id=319>. Acessed on: 19 Sep. 2014.

JAIS WAL, B.S.; KLJAVIN, N.M.; STAWISKI, E.W.; CHAN, E.; PARIKH, C.; DURINCK, S.; CHAUDHURI, S.; PUJARA, K.; GUILLORY, J.; EDGAR, K.A.; JANAKIRAMAN, V.; SCHOLZ, R.P.; BOWMAN, K.K.; LORENZO, M.; LI, H.; WU, J.; YUAN, W.; PETERS, B.A.; KAN, Z.,; STINSON, J.; MAK, M.; MODRUSAN, Z.; EIGENBROT, C.; FIRESTEIN, R.; STERN, H.M.; RAJALINGAM, K.; SCHAEFER, G.; MERCHANT, M.A.; SLIWKOWSKI, M.X.; DE SAUVAGE, F.J.; SESHAGIRI S. Oncogenic ERBB3 mutations in human cancers. Cancer Cell, v.23, n.5, p.603-617, 2013. 
JOOS, S.; KÜPPER, M.; OHL, S.; VON BONIN, F.; MECHTERSHEIMER, G.; BENTZ, M.; MARYNEN, P.; MÖLLER, P.; PFREUNDSCHUH, M.; TRÜMPER, L.; LICHTER, P. Genomic imbalances including amplification of the tyrosine kinase gene JAK2 in CD30+ Hodgkin cells. Cancer Res., v.60, n.3, p.549-552, 2000.

KINGWELL, K. Receptor pharmacology: the many faces of G protein-coupled receptors. Nat. Rev. Drug Discov., v.15, n.9, p.602-603, 2016.

LASSUS, H.; SIHTO, H.; LEMINEN, A.; JOENSUU, H.; ISOLA, J.; NUPPONEN, N.N.; BUTZOW, R. Gene amplification, mutation, and protein expression of EGFR and mutations of ERBB2 in serous ovarian carcinoma. $J$. Mol. Med., v.84, n.8, p.671-681, 2006.

LEE, Y.; MA, J.; LYU, H.; HUANG, J.; KIM, A.; LIU, B. Role of ErbB3 receptors in cancer therapeutic resistance. Acta Biochim. Biophys. Sinica, v.46, n.3, p.190-198, 2014.

LEE-HOEFLICH, S.T.; CROCKER, L.; YAO, E.; PHAM, T.; MUNROE, X.; HOEFLICH, K.P.; SLIWKOWSKI, M.X.; STERN, H.M. A central role for HER3 in HER2-amplified breast cancer: implications for targeted therapy. Cancer Res., v.68, n.14, p.5878-5887, 2008.

LEMMON, M.A.; SCHLESSINGER, J. Cell signaling by receptor tyrosine kinases. Cell, v.141, n.7, p.1117-1134, 2010

LILES, J.S.; ARNOLETTI, J.P.; TZENG, C.W.; HOWARD, J.H.; KOSSENKOV, A.V.; KULESZA, P.; HESLIN, M.J.; FROLOV, A. ErbB3 expression promotes tumorigenesis in pancreatic adenocarcinoma. Cancer Biol. Ther., v.10, n.6, p.555-563, 2010.

LUDOVINI, V.; BIANCONI, F.; PISTOLA, L.; CHIARI, R.; MINOTTI, V.; COLELLA, R.; GIUFFRIDA, D.; TOFANETTI, F. R.; SIGGILLINO, A.; FLACCO, A.; BALDELLI, E.; IACONO, D.; MAMELI, M.G.; CAVALIERE, A.; CRINÒ, L. Phosphoinositide-3-kinase catalytic alpha and KRAS mutations are important predictors of resistance to therapy with epidermal growth factor receptor tyrosine kinase inhibitors in patients with advanced non-small cell lung cancer. J. Thoracic. Oncol., v.6, n.4, p.707-715, 2011.

MARMOR, M.D.; SKARIA, K.B.; YARDEN, Y. Signal transduction and oncogenesis by ErbB/HER receptors. Int. J. Radiat. Oncol., v.58, n.3, p.903-913, 2004.
MCINTYRE, E.; BLACKBURN, E.; BROWN, P.J.; JOHNSON, C.G.; GULLICK, W.J. The complete family of epidermal growth factor receptors and their ligands are co-ordinately expressed in breast cancer. Breast Cancer Res. Treat., v.122, n.1, p.105-110, 2010.

MENDELSOHN, J.; BASELGA, J. Status of epidermal growth factor receptor antagonists in the biology and treatment of cancer. J. Clin. Oncol., v.21, n.14, p.2787-2799, 2003.

MIETTINEN, P.J.; BERGER, J.E.; MENESES, J.; PHUNG, Y.; PEDERSEN, R.A.; WERB, Z. DERYNCK, R. Epithelial immaturity and multiorgan failure in mice lacking epidermal growth factor receptor. Nature, v.376, n.6538, p.337-341, 1995.

MOREL, M.; VANDERSTRAETE, M.; HAHNEL, S.; GREVELDING, C.G.; DISSOUS, C. Receptor tyrosine kinases and schistosome reproduction: new targets for chemotherapy. Front. Gen., v.5, n.238, p.1-5, 2014.

NEUBAUER, H.; CUMANO, A.; MÜLLER, M.; WU, H.; HUFFSTADT, U.; PFEFFER, K. Jak2 deficiency defines an essential developmental checkpoint in definitive hematopoiesis. Cell, v.93, n.3, p.397-409, 1998.

NIELSEN, T.O.; FRIIS-HANSEN, L.; POULSEN, S.S.; FEDERSPIEL, B.; SORENSEN, B.S. Expression of the EGF family in gastric cancer: downregulation of HER4 and its activating ligand NRG4. PLoS ONE, v.9, n.4, p.e94606, 2014.

OHNO, S. Tolerability of therapies recommended for the treatment of hormone receptor-positive locally advanced or metastatic breast cancer. Clin. Breast Cancer, v.16, n.4, p.238-246, 2016.

O’SHEA, J.J.; HOLLAND, S.M.; STAUDT, L.M. JAKs and STATs in immunity, immunodeficiency, and cancer. N. Eng. J. Med., v.368, n.2, p.161-170, 2013.

ORCY, R.B.; SCHROEDER, S.; MARTINS-COSTA, S.H.; RAMOS, J.G.; SCHECHINGER, W.; KLEIN, H.; BRUM, I.S.; VON EYE CORLETA, H.; CAPP, E. Signalization of $\mathrm{Akt} / \mathrm{PKB}$ in the placenta, skeletal muscle and adipose tissue of preeclampsia patients. Gynecol. Obstet. Invest., v.66, n.4, p.231-236, 2008.

PARK, J.I. Growth arrest signaling of the Raf/MEK/ERK pathway in cancer. Front. Biol., v.9, n.2, p.95-103, 2014. 
PROCTER, M.; SUTER, T.M.; DE AZAMBUJA, E.; DAFNI, U.; VAN DOOREN, V.; MUEHLBAUER, S.; CLIMENT, M.A.; RECHBERGER, E.; LIU, W.T.; TOI, M.; COOMBES, R.C.; DODWELL, D.; PAGANI, O.; MADRID, J.; HALL, M.; CHEN, S. C.; FOCAN, C.; MUSCHOL, M.; VAN VELDHUISEN, D.J.; PICCARTGEBHART, M.J. Longer-term assessment of trastuzumabrelated cardiac adverse events in the Herceptin Adjuvant (HERA) trial. J. Clin. Oncol., v.28, n.21, p.3422-3428, 2010 .

PRENZEL, N.; ZWICK, E.; LESERER, M.; ULLRICH, A. Tyrosine kinase signalling in breast cancer: Epidermal growth factor receptor - convergence point for signal integration and diversification. Breast Cancer Res., v.2, n.3, p.184-190, 2000.

RED BREWER, M.; CHOI, S.H.; ALVARADO, D.; MORAVCEVIC, K.; POZZI, A.; LEMMON, M.A.; CARPENTER, G. The juxtamembrane region of the EGF receptor functions as an activation domain. Mol. Cell, v.34, n.6, p.641-651, 2009.

RESCHKE, M.; MIHIC-PROBST, D.; VAN DER HORST, E. H.; KNYAZEV, P.; WILD, P. J.; HUTTERER, M.; MEYER, S.; DUMMER, R.; MOCH, H.; ULLRICH, A. HER3 is a determinant for poor prognosis in melanoma. Clin. Cancer Res., v.14, n.16. p.5188-5197, 2008.

REXER, B.N.; ARTEAGA, C.L. Intrinsic and Acquired resistance to HER2-targeted therapies in HER2 geneamplified breast cancer: mechanisms and clinical implications. Crit. Rev. Oncog., v.17, n.1, p.1-16, 2012.

RIETHMACHER, D; SONNENBERG-RIETHMACHER, E.; BRINKMANN, V.; YAMAAI, T.; LEWIN, G. R.; BIRCHMEIER, C. Severe neuropathies in mice with targeted mutations in the ErbB3 receptor. Nature, v.389, n.6652, p.725-730, 1997.

RODIG, S.J.; MERAZ, M.A.; WHITE, J.M.; LAMPE, P.A.; RILEY, J.K.; ARTHUR, C.D.; KING, K. L.; SHEEHAN, K.C.; YIN, L.; PENNICA, D.; JOHNSON, E.M.Jr; SCHREIBER, R.D. Disruption of the Jak1 gene demonstrates obligatory and nonredundant roles of the Jaks in cytokine-induced biologic responses. Cell, v.93, n.3, p.373-383, 1998.
RYAN, Q.; IBRAHIM, A.; COHEN, M.H.; JOHNSON, J.; KO, C.W.; SRIDHARA, R.; JUSTICE, R.; PAZDUR, R. FDA drug approval summary: lapatinib in combination with capecitabine for previously treated metastatic breast cancer that overexpresses HER-2. Oncologist, v.13, n.10, p.1114-1119, 2008 .

SANSONE, P.; BROMBERG, J. Targeting the Interleukin-6/ Jak/Stat pathway in human malignancies. J. Clin. Oncol., v.30, n.9, p.1005-1014, 2012.

SARDI, S.P.; MURTIE, J.; KOIRALA, S.; PATTEN, B.A.; CORFAS, G. Presenilin-dependent ErbB4 nuclear signaling regulates the timing of astrogenesis in the developing brain. Cell, v.127, n.1, p.185-197, 2006.

SCALTRITI, M.; ROJO, F.; OCAÑA, A.; ANIDO, J.; GUZMAN, M.; CORTES, J.; DI COSIMO, S.; MATIASGUIU, X.; RAMON, Y.; CAJAL, S.; ARRIBAS, J.; BASELGA, J. Expression of p95HER2, a truncated form of the HER2 receptor, and response to anti-HER2 therapies in breast cancer. J. Natl. Cancer Inst., v.99, n.8, p.628-638, 2007.

SCALTRITI, M.; EICHHORN, P.J.; CORTÉS, J.; PRUDKIN, L.; AURA, C.; JIMÉNEZ, J.; CHANDARLAPATY, S.; SERRA, V.; PRAT, A.; IBRAHIM, Y.H.; GUZMÁN, M.; GILI, M.; RODRÍGUEZ, O.; RODRÍGUEZ, S.; PÉREZ, J.; GREEN, S.R.; MAI, S.; ROSEN, N.; HUDIS, C.; BASELGA, J. Cyclin E amplification/overexpression is a mechanism of trastuzumab resistance in HER2+ breast cancer patients. Proc. Natl. Acad. Sci. USA, v.108, n.9, p.3761-3766, 2011.

SCHULZE, W.X.; DENG, L.; MANN, M. Phosphotyrosine interactome of the ErbB-receptor kinase family. Mol. Syst. Biol., v.1, n.1, p.1-13, 2005.

SCHWARTZBERG, L.S.; FRANCO, S.X.; FLORANCE, A.; O’ROURKE, L.; MALTZMAN, J.; JOHNSTON, S. Lapatinib plus letrozole as first-line therapy for HER$2+$ hormone receptor-positive metastatic breast cancer. Oncologist, v.15, n.2, p.122-129, 2010.

SEOANE, S.; MONTERO, J.C.; OCAÑA, A.; PANDIELLA, A. Effect of multikinase inhibitors on caspase-independent cell death and DNA damage in HER2-overexpressing breast cancer cells. J. Natl. Cancer Inst., v.102, n.18, p.1432-1446, 2010. 
SHI, F.; TELESCO, S.E.; LIU, Y.; RADHAKRISHNAN, R.; LEMMON, M.A. ErbB3/HER3 intracellular domain is competent to bind ATP and catalyze autophosphorylation. Proc. Natl. Acad. Sci. USA, v.107, n.17, p.7692-7697, 2010.

SHUPTRINE, C.; SURANA, R.; WEINER, L.M. Monoclonal antibodies for the treatment of cancer. Semin. Cancer Biol., v.22, n.1, p.3-13, 2012.

SIEGEL, R.; NAISHADHAM, D.; JEMAL, A. 2013. Cancer statistics, 2013. CA Cancer J. Clin., v.63. n.1, p.11-30, 2013.

SIHTO, H.; PUPUTTI, M.; PULLI, L.; TYNNINEN, O.; KOSKINEN, W.; AALTONEN, L.M.; TANNER, M.; BÖHLING, T.; VISAKORPI, T.; BÜTZOW, R.; KNUUTTILA, A.; NUPPONEN, N. N.; JOENSUU, H. Epidermal growth factor receptor domain II, IV, and kinase domain mutations in human solid tumors. J. Mol. Med., v.83, n.12, p.976-983, 2005.<<esta referência não é citada no texto. retire a referência ou insira a citação $>>$

SMIRNOVA, T.; ZHOU, Z.N.; FLINN, R.J.; WYCKOFF, J.; BOIMEL, P.J.; POZZUTO, M.; CONIGLIO, S.J.; BACKER, J.M.; BRESNICK, A.R.; CONDEELIS, J.S.; HYNES, N.E.; SEGALL, J.E. Phosphoinositide 3-kinase signaling is critical for ErbB3-driven breast cancer cell motility and metastasis. Oncogene, v.31, n.6, p.706-715, 2011.

SPECTOR, N.L.; BLACKWELL, K.L. Understanding the mechanisms behind trastuzumab therapy for human epidermal growth factor receptor 2-positive breast cancer. J. Clin. Oncol., v.27, n.34, p.5838-5847, 2009.

SUDA, K.; MIZUUCHI, H.; MAEHARA, Y.; MITSUDOMI, T. Acquired resistance mechanisms to tyrosine kinase inhibitors in lung cancer with activating epidermal growth factor receptor mutationdiversity, ductility, and destiny. Cancer Metastasis Rev., v.31, n.4, p.807-814, 2012.

SULLIVAN, L.B.; GUI, D.Y.; VANDER HEIDEN, M.G. Altered metabolite levels in cancer: implications for tumour biology and cancer therapy. Nat. Rev. Cancer, v.16, n.11, p.680-693, 2016.

SUTHERLAND, R.L. Endocrine resistance in breast cancer: new roles for ErbB3 and ErbB4. Breast Cancer Res., v.13, n.3, p.106, 2011.
TURAL, D.; AKAR, E.; MUTLU, H.; KILICKAP, S. P95 HER2 fragments and breast cancer outcome. Expert Rev. Anticancer Ther., v.8, n.1, p.1-8, 2014.

TZAHAR, E.; WATERMAN, H.; CHEN, X.; LEVKOWITZ, G.; KARUNAGARAN, D.; LAVI, S.; RATZKIN, B.J.; YARDEN, Y. A hierarchical network of interreceptor interactions determines signal transduction by $\mathrm{Neu}$ differentiation factor/neuregulin and epidermal growth factor. Mol. Cell Biol., v.16, n.10, p.5276-5287, 1996.

VAHEDI, G.; TAKAHASHI, H.; NAKAYAMADA, S.; SUN, H.W.; SARTORELLI, V.; KANNO, Y.; O'SHEA, J.J. STATs shape the active enhancer landscape of T cell populations. Cell, v.151, n.5, p.981-993, 2012.

VIVANCO, I.; SAWYERS, C.L. The phosphatidylinositol 3-Kinase AKT pathway in human cancer. Nature Rev. Cancer, v.2, n.7, p.489-501, 2002.

VLAHOVIC, G.; CRAWFORD, J. Activation of tyrosine kinases in cancer. Oncologist, v.8, n.6, p.531-538, 2003.

VON MINCKWITZ, G. Docetaxel/anthracycline combinations for breast cancer treatment. Expert Opin. Pharmacother., v.8, n.4, p.485-495, 2007.

WAGNER, J.P.; WOLF-YADLIN, A.; SEVECKA, M.; GRENIER, J.K.; ROOT, D.E.; LAUFFENBURGER, D.A.; MACBEATH, C. Receptor tyrosine kinases fall into distinct classes based on their inferred signaling networks. Sci. Signaling, v.6, n.284, p.ra58, 2013.

WEINBERG, R.A. Cancer biology. Porto Alegre: Artmed, 2008. 864p.

WITTLIFF, J.L. Steroid-hormone receptors in breast cancer. Cancer, v.51, n.3, p.630-643, 1984.

WONG, A.J.; RUPPERT, J.M.; BIGNER, S.H.; GRZESCHIK, C.H.; HUMPHREY, P.A.; BIGNER, D.S.; VOGELSTEIN, B. Structural alterations of the epidermal growth factor receptor gene in human gliomas. Proc. Natl. Acad. Sci. USA, v.89, n.7, p.2965-2969, 1992.

WORLD HEALTH ORGANIZATION. WHO. All Cancers (excluding non-melanoma skin cancer). Estimated incidence, mortality and prevalence worldwide in 2012. Switzerland: World Health Organization, 2012. Available at: $<$ http://globocan.iarc.fr/Pages/fact_sheets_cancer.aspx $>$. Acessed on: 20 Nov. 2014. 
XU, L.; ZHAO, Y.; CHEN, Z.; WANG, Y.; CHEN, L.; WANG, $\mathrm{S}$. Tamoxifen and risk of contralateral breast cancer among women with inherited mutations in BRCA1 and BRCA2: a meta-analysis. Breast Cancer, v.22, n.4, p.327-334, 2015.
YARDEN, Y.; SLIWKOWSKI, M.X. Untangling the ErbB signalling network. Nature Rev. Mol. Cell Biol., v.2, n.2, p.127-137, 2001.

Received for publication on $28^{\text {th }}$ April 2016 Accepted for publication on $22^{\text {nd }}$ February 2017 